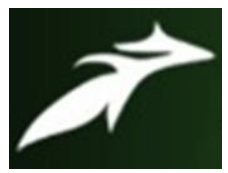

Shravan Choudhary et al, International Journal of Advances in Agricultural Science and Technology,

Vol.8 Issue.3, March-2021, pg. 1-9

ISSN: 2348-1358

Impact Factor: 6.057

NAAS Rating: 3.77

\title{
STUDY ON CONSUMER BEHAVIOUR FOR BAKERY PRODUCTS
}

\author{
Shravan Choudhary $^{1}$; Er. Dorcus Masih ${ }^{2}$; Er. Chitra Sonkar ${ }^{3}$; Pooja Chaudhary ${ }^{4}$ \\ ${ }^{1}$ M.Tech (Food Technology), Department of Food Process Engineering, SHUATS, Prayagraj, India \\ ${ }^{2}$ Assistant Professor and Head, Department of Food Process Engineering, SHUATS, Prayagraj, India \\ ${ }^{3}$ Assistant Professor, Department of Food Process Engineering, SHUATS, Prayagraj, India \\ ${ }^{4}$ M.Tech (Food Technology), Department of Food Process Engineering, SHUATS, Prayagraj, India \\ Corresponding Author: sambaliyan52@ gmail.com \\ DOI: 10.47856/ijaast.2021.v08i3.001
}

\begin{abstract}
Due to the change in lifestyle, consumption of bakery products increases rapidly worldwide. This study was done to understand the behavior of consumers towards bakery products on the basis of various factors like age group and gender of consumers, flavor, texture, taste, odor, price of bakery products. Data was collected by survey (questionnaire) in the form of responses and these responses were analyzed by using chi-square test to test the relationship between different categorical variables. Objectives of this study were to study the different factors influencing the selection of bakery products and to study the consumer behavior towards bakery products. According to the study, males of 20 to 40 years age group involved in services (jobs) were highest consumer of bakery products i.e. 82\%. Another finding of this study was, factors (flavor, texture, raw material, odor, smell, price of bakery products) directly influence consumers buying decision. With the help of Chi-square test a satisfactory relationship was obtained between these variables i.e. for raw material $X^{2}>0.17908(d f=1)$, for flavor $X^{2}>0.73588(d f=1)$, for fortification $X^{2}>0.02518(d f=1)$, for nutritive value $X^{2}>0.012216(d f=1)$. Overall a positive behavior of consumers was recorded by this research.
\end{abstract}

Keywords: Consumer behavior, Bakery products, customer satisfaction, Survey, Chi-square test

\section{Introduction}

A Baking industry is characterized with a variety of different products that daily find their place on the market. Their quality estimate all possible generations of consumers. Stable quality of production, from the long-term point of view, is not easy to preserve (Artalejo et.al, 2002). The history about bread dates back to ancient Egypt, for over 10,000; where they used to crop grains along the Nile River for bred production. Although such food was used as compensation forms at work, they were found to be basic and showed a social importance (Franklin, 2003). It believes that for around the year $2500 \mathrm{BC}$, bakers began producing the first fermented breads. However, according to Ramos (2011), the oldest evidence of fermented bread consumption was also found in ancient Egypt and date back to around $3000 \mathrm{BC}$. In addition, some historians state that the yeast was used for bread-making purposes in the prehistoric period. Bakery industry is the rapidly growing industry in our country. This industry in India is the largest of the food industries with an annual turnover of about Rs 3,000 crore. India is the second largest producer of biscuits in the world. The bakery industry is divided into two main types: Individual bakers in tiny sector catering to the requirements of their local markets and the Industrial bakers of the Fast Moving Consumer Goods (FMCG) in the category of major industrial units having market operations in many parts of the country (Saranraj et.al, 2011). The growth of the bakery products has reduced the responsibilities of kitchen. They can now easily prepare food with the readymade food items which need less labour and time. Increased awareness of the bakery products has reduced the burden of the females in the society. People going out of home can easily satisfy their food needs. Thus the bakery products have solved many problems of the people (Smith et.al, 2010). The two most important bakery products viz., bread and biscuits accounts about $81 \%$ of the whole bakery products. The yearly manufacturing of bakery products which includes bread, biscuits, pastries, cakes, buns, etc. are from both the organized and unorganized sectors, which comprises 15 lakh tonnes most of which are in the organized sector is estimated to be around 31 lakh tonnes. The production of bakery products in both is estimated to be around 15 lakh tones and 11 lakh tones respectively. With the changing lifestyle and income level, people are shifting their consumption patterns and have 


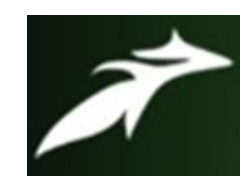

Shravan Choudhary et al, International Journal of Advances in Agricultural Science and Technology,

Vol.8 Issue.3, March-2021, pg. 1-9

ISSN: 2348-1358

Impact Factor: 6.057

NAAS Rating: 3.77

therefore become more health conscious thus leading to increase in demand of Bakery products. In modern days bakery products are becoming one of the most essential food items in human diet due to readymade availability and high nutritive value. Thus the present day market research is based on consumer behavior towards bakery products.

\section{Materials and Methods:}

"Study on Consumer behavior for Bakery products" was done under Department of Food Process Engineering, Vaugh Institute of Agriculture, Engineering and Technology, Sam Higginbottom University of Agriculture, Technology \& Sciences, (Naini) Prayagraj, Uttar Pradesh, India.

\subsection{Sources of data collection:}

- Primary data: Questionnaire- Primary data was collected by preparing questionnaire and the people were randomly requested to fill them.

- Secondary data- Secondary data was consisting of different literatures like books which are published, articles, journals, magazines, internet and websites.

\subsection{Selection of sample size:}

For the study, a sample size of 100 was taken into consideration.

\subsection{Statistical tools used:}

The main statistical tools used for the analyses of data in this research were:

a) Pie chart: Pie chart is used to represent the data in percentage, obtained from survey.

b) Bar diagrams: Bar diagram is used to represent the numeric value (exact value) of the data obtained from survey.

c) Chi-square test: Chi-square test is used to analyze the data obtained from survey at 5\% significance level.

To fulfill the objectives of research work various questions responses was taken into consideration for chi-square analysis.

\section{Results}

"Study on Consumer behavior for Bakery products" was carried out by circulating a questionnaire in a random population. Responses from each person were evaluated thoroughly for each question. Overall 110 responses were recorded and used for analysis.

In 110 responses 90 are males and 20 are females i.e. $82 \%$ and $18 \%$ respectively. The consumers are belongs to different location in India like Uttar Pradesh (Allahabad, Meerut, Mathura, Muzaffarnagar, Varansi, Lucknow, Saharanpur, Kanpur) and Rajasthan (Kota, Jaipur, Jodhpur), Delhi, Haryana (Gurgaon, Faridabad, ). Bakery products are consumed at every place, persons who do not like bakery products are very low in numbers i.e. only 6 in 110 responses. Most of the peoples like bakery products i.e. 104 in 110 responses. Due to rapid change in lifestyle of peoples and income, consumption of bakery products increases.

\subsection{Influence of different factors on the selection of bakery products-}

Influence of age and occupation- Different age group/occupation has different perceptions and preferences for food products. Consumers' behavior towards a particular food product is changed according to the age and occupation. According to the this survey, highest consumer of bakery products are the peoples of age group of 20 to 40 years and having service as an occupation. The responses obtained are shown below in the form of pie chart. 


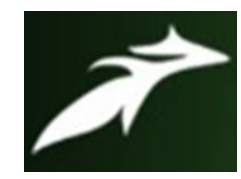

Shravan Choudhary et al, International Journal of Advances in Agricultural Science and Technology,

Vol.8 Issue.3, March-2021, pg. 1-9

ISSN: 2348-1358

Impact Factor: 6.057

NAAS Rating: 3.77

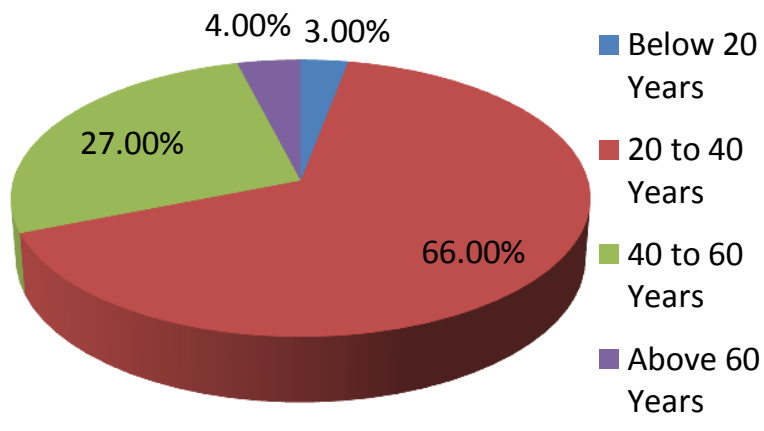

Figure 1: Responses for age

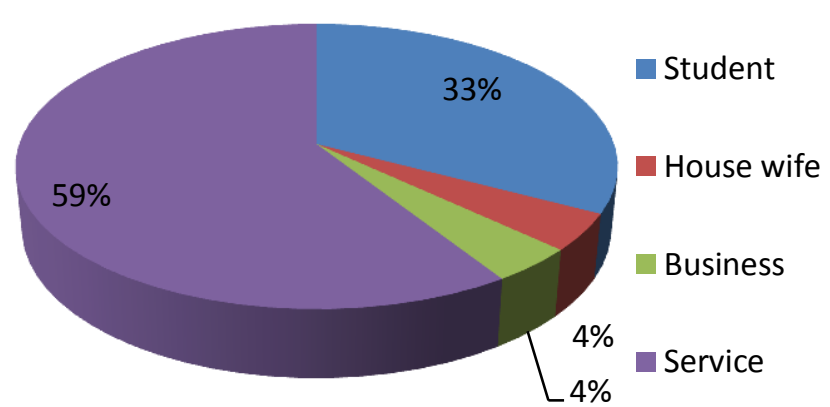

Figure 2: Responses for occupation

Table 1: Chi-square test result $(P=0.05, \mathrm{df}=3)$

\begin{tabular}{|c|c|c|c|c|c|}
\hline \multirow{2}{*}{\multicolumn{2}{|c|}{ Parameter }} & \multicolumn{2}{|c|}{ Responses } & \multirow{2}{*}{$\mathbf{X}^{2}$ (Calculated) } & \multirow{2}{*}{$X^{2}$ (Tabulated) } \\
\hline & & Yes & No & & \\
\hline \multirow{4}{*}{ Age } & Below 20 years & 3 & 0 & \multirow{4}{*}{9.109113} & \multirow{4}{*}{7.815} \\
\hline & 20 to 40 Years & 72 & 1 & & \\
\hline & 40 to 60 Years & 26 & 4 & & \\
\hline & Above 60 Years & 3 & 1 & & \\
\hline \multirow{4}{*}{ Occupation } & Student & 33 & 3 & \multirow{4}{*}{4.542653} & \multirow{4}{*}{7.815} \\
\hline & Housewife & 3 & 1 & & \\
\hline & Business & 5 & 0 & & \\
\hline & Services & 63 & 2 & & \\
\hline
\end{tabular}

Results obtained from research shows that 3 persons are below 20 years i.e. 3\% of the total responses, 73 persons are between 20 to 40 years i.e. $66 \%$ of the total responses, 30 persons are between 40 to 60 years i.e. $27 \%$ of the total responses and 4 persons are above 60 years i.e. $4 \%$ of total responses. 36 persons are student i.e. $33 \%$ of the total responses, 4 are housewife i.e. $4 \%$ of the total responses, 5 are in business i.e. $4 \%$ of the total responses and 65 are in services i.e. 59\% of the total responses. Based on the available data, present study shows that bakery consumption increases from past few years and highest consumer of the bakery products are the peoples of 20 to 40 age group having service as an occupation. Most of the people of this age group are having a busy schedule and don't have enough time to make or cook their food so these people prefer ready to eat food like bakery products because of their work load. Easy availability of bakery products in restaurants, messes, canteens, hostels and near to the place of stay (neighborhood stores) makes the purchase and consumption of bakery products easier and frequent. Bakery products fulfill the requirement of essential nutrients and because of their taste, color, flavor, bakery products mostly preferred in any celebration like (office celebration, birthday celebration etc.). In present research, influence of age and occupation on consumption of bakery products analyzed by using Chi-square test and a good relationship between categorical variables was obtained (Table 1) which is similar to the research done by Gul et.al (2017) for bakery products consumption and consumers' awareness in urban areas of isparta city, turkey. In his research the findings was about 


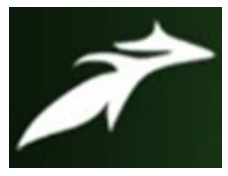

Shravan Choudhary et al, International Journal of Advances in Agricultural Science and Technology,

Vol.8 Issue.3, March-2021, pg. 1-9

ISSN: 2348-1358

Impact Factor: 6.057

NAAS Rating: 3.77

$15.97 \%$ of the individuals were in the 18-24 group, $26.74 \%$ in the $25-34$ age group, $23.96 \%$ in the $35-44$ age group, $25.69 \%$ in the $45-$ 54 age group, $6.94 \%$ in the $55-64$ age group and $0.69 \%$ were 65 years of age or older. It was found that $19.10 \%$ of the interviewed individuals worked in the public sector, $21.53 \%$ in the private sector, $13.19 \%$ of the interviewed individuals worked in their own workplace and $10.07 \%$ of the interviewed individuals were also in paid employment. It was determined that $20.83 \%$ of the interviewees were housewives, $7.64 \%$ were retired and $7.64 \%$ were unemployed. These results obtained by previous research supports the results of the present research.

Influence of raw material, flavor, fortification and nutritive value- Quality of baked product depends on raw material used, nutritive value of material used, fortification done in baked product and flavor added to the product. Effect of these factors on consumption of bakery products was evaluated by doing a survey.

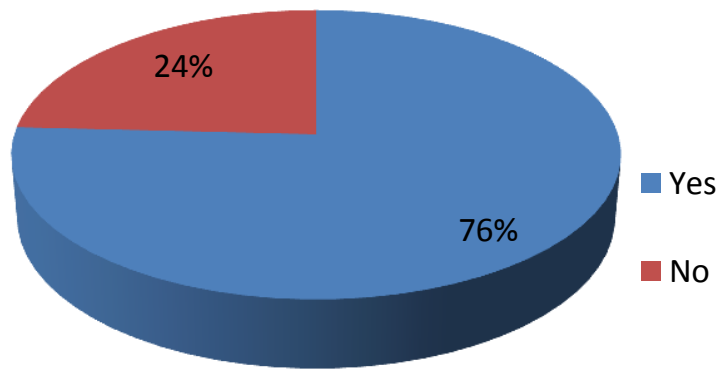

Figure 3: Responses for Raw material

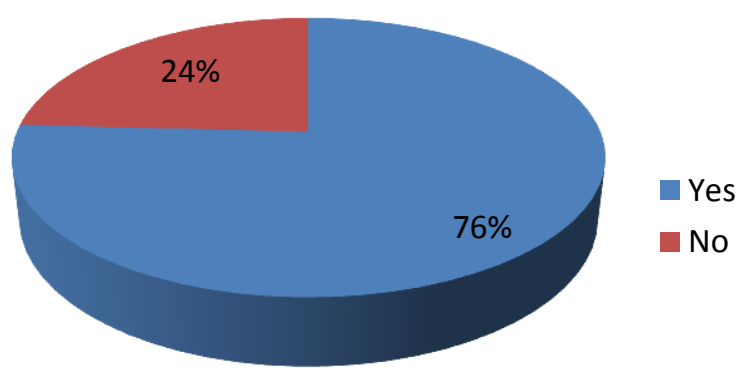

Figure 5: Responses for Fortification

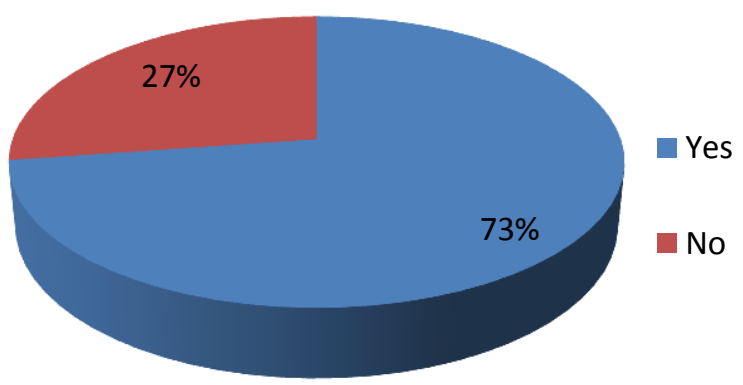

Figure 4: Responses for Flavor

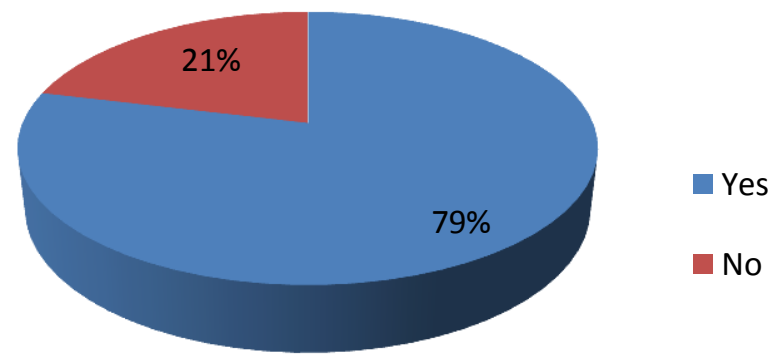

Figure 6: Responses for Nutritive value

Table 2: Chi-square Test result $(P=0.05, d f=1)$

\begin{tabular}{|c|c|c|c|c|}
\hline \multirow{2}{*}{ Parameter } & \multicolumn{2}{|c|}{ Responses } & \multirow{2}{*}{$X^{2}($ Calculated $)$} & \multirow{2}{*}{$\mathbf{X}^{2}$ (Tabulated $)$} \\
\hline & Yes & No & & \\
\hline Raw material & 84 & 26 & 0.17908 & 3.841 \\
\hline Flavor & 80 & 30 & 0.73588 & 3.841 \\
\hline
\end{tabular}




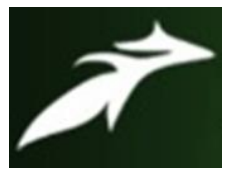

Shravan Choudhary et al, International Journal of Advances in Agricultural Science and Technology, Vol.8 Issue.3, March-2021, pg. 1-9

ISSN: 2348-1358

Impact Factor: 6.057

NAAS Rating: 3.77

\begin{tabular}{|c|c|c|c|c|}
\hline Fortification & 84 & 26 & 0.025183 & 3.841 \\
\hline Nutritive value & 87 & 23 & 0.012216 & 3.841 \\
\hline
\end{tabular}

Results obtained from research shows that, for raw material 84 responses were for yes and 26 responses were for no, for flavor 80 responses were for yes and 30 were for no, for fortification 84 responses was for yes and 26 was for no, for nutritive value 87 responses was for yes and 23 was for no. Raw material used to prepare any products affects product quality and customer acceptance. In bakery products mainly used raw materials are wheat flour, oat flour and multigrain flour. These raw materials use according to the requirement such as nutritive value, taste, price etc. Baked products prepared by these flours have different characteristics in terms of the flavor, smell, texture, nutritive value and consumer acceptance. That's why raw material used to prepare bakery products affects consumers buying decision and a very important factor to taken into consideration for any baker or bakery industry to satisfy the consumer. Chi-square test result shows a satisfactory relationship between variables obtained from the survey for raw material. Flavor of bakery products rely on raw material and condition of baking. Consumers are very specific in flavor so to fulfill the consumers demand additional flavor are also mixed in bakery products. Addition of other materials like sweetener, nutrients, color, food ingredients like coconut, jeera, methi, egg etc. in bakery products are known as fortification in bakery products. Fortification is done to meet the requirements of the consumers. In the same way nutritive value of the products are also important in the term of consumer satisfaction and a strong relationship is also obtained between these variables by Chi-square test (Table 2) . Results of previous research done by Kannan, 2017 supports the findings of present research that is the variables of quality such as Taste, Health Factor, Ingredients, and Variety of products constituted in Factor 1 with higher factor loading. The higher amount of communality for the four variables indicate that higher amount of variance is explained by the extracted factors. The included four variables explain this Factor to the extent of 71.0 percent. Similar results were also find by Maric, 2009 in his research.

Influence of color, texture, taste and smell- These are the parameters by which quality and acceptance of a product is measure. Effect of these factors on consumer's buying decision was tested and results are:

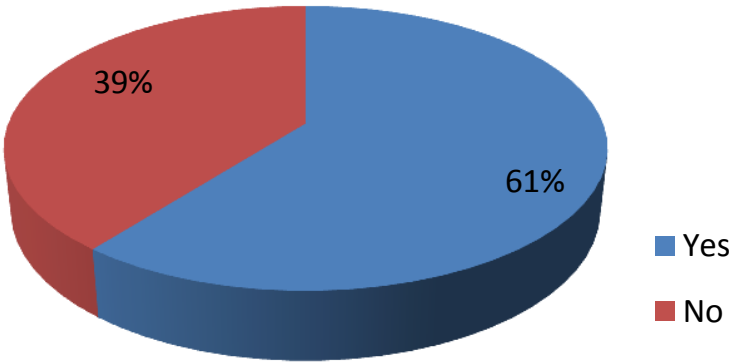

Figure 7: Responses for Color

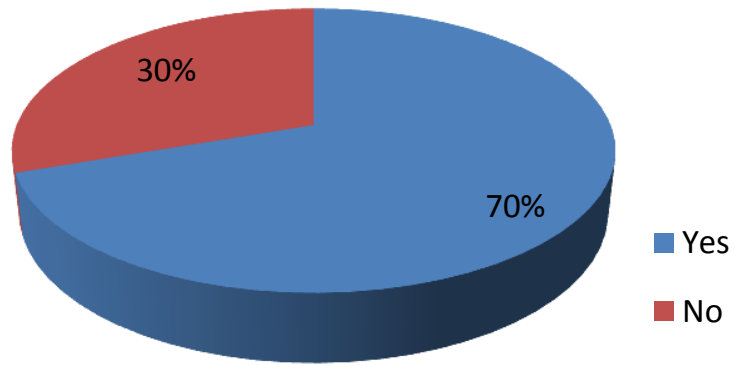

Figure 8: Responses for Texture 


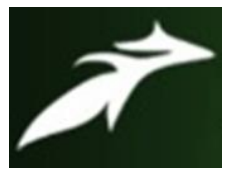

Shravan Choudhary et al, International Journal of Advances in Agricultural Science and Technology,

Vol.8 Issue.3, March-2021, pg. 1-9

ISSN: 2348-1358

Impact Factor: 6.057

NAAS Rating: 3.77

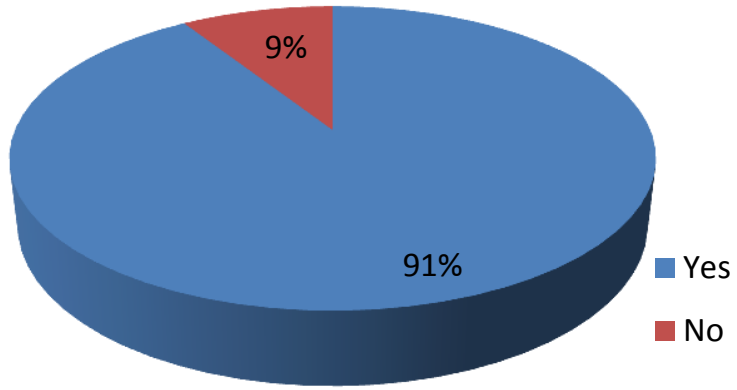

Figure 9: Responses for Taste

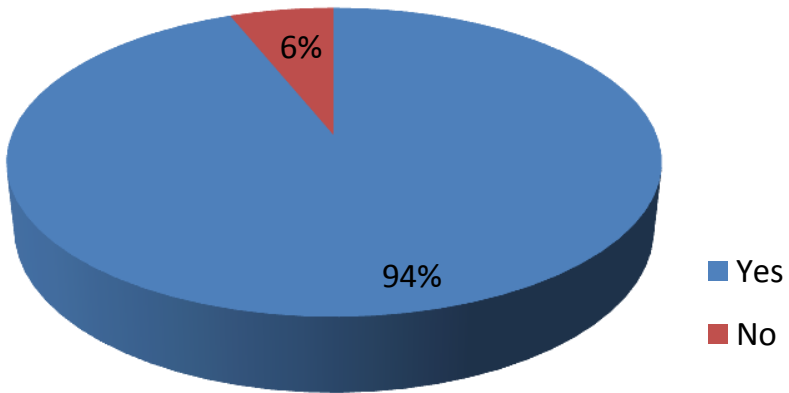

Figure 10: Responses for Smell

Table 3: Chi-square Test result $(P=0.05, \mathrm{df}=1)$

\begin{tabular}{|c|c|c|c|c|}
\hline \multirow{2}{*}{ Parameters } & \multicolumn{2}{|c|}{ Responses } & \multirow{2}{*}{$\mathbf{X}^{2}$ (Calculated) } & \multirow{2}{*}{$\mathbf{X}^{2}$ (Tabulated) } \\
\cline { 2 - 4 } & Yes & No & 0.008485 & 3.841 \\
\hline Color & 67 & 43 & 0.291005 & 3.841 \\
\hline Texture & 77 & 33 & 1.032778 & 3.841 \\
\hline Taste & 100 & 10 & 3.059793 & 3.841 \\
\hline
\end{tabular}

Results obtained from research shows that for color 67 responses was for yes and 43 was for no, for texture 77 responses was for yes and 33 was for no, for taste 100 responses was for yes and 10 was for no, for smell 103 responses was for yes and 7 was for no. These factors are the major factors in determination of the product acceptance. Color of the baked product like biscuit, cookies, pastries, cakes etc. influence consumers buying decision because different colors attracts different consumers. This is the main reason of the wide range of bakery products available in market with different color. Color is the initial character or attribute of the product so it is important to understand the preference of consumers towards color of the bakery products. In present research $61 \%$ individuals says yes for the color importance. In the same way texture of the bakery products is also important because consumer's preferences are different in terms of texture. Some consumers prefer hardness in a particular product while on the other hand some consumers prefer softness in that product. There is a range of the bakery products having different texture in the market according to the consumers need and research done by Maric, 2009 supports the findings of the present research. Taste and smell or odor of the bakery products strongly influences consumers buying decision because consumers prefer a pleasant aroma or odor from food products. Consumers don't like any unpleasant aroma or odor of food products. Smell of any food product create an image in consumers mind about taste of the food product and if the smell or taste does not meet or fulfill the consumers requirement then consumer does not want to consume that food product. A good relationship is also shows by the variables in this research for influence of color, texture, taste and smell (Table 3). 


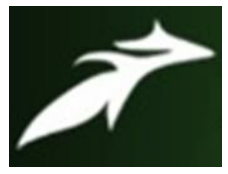

Shravan Choudhary et al, International Journal of Advances in Agricultural Science and Technology,

Vol.8 Issue.3, March-2021, pg. 1-9

ISSN: 2348-1358

Impact Factor: 6.057

NAAS Rating: 3.77

\subsection{Influence of bakery products on consumer behavior-}

Influence of different bakery products- Choice of every person is different in many ways. In foods products different consumer likes different product. This like or dislike for of consumers comes under consumer behavior towards that product.

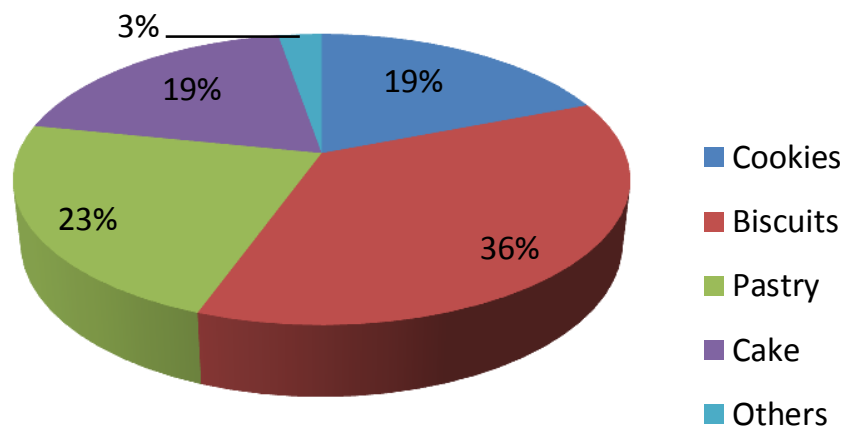

Figure 11: Responses for different Bakery products

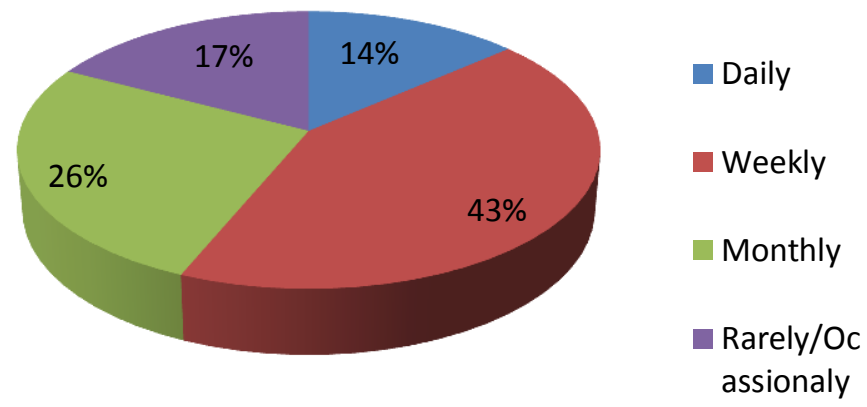

Figure 12: Responses for frequency of buying

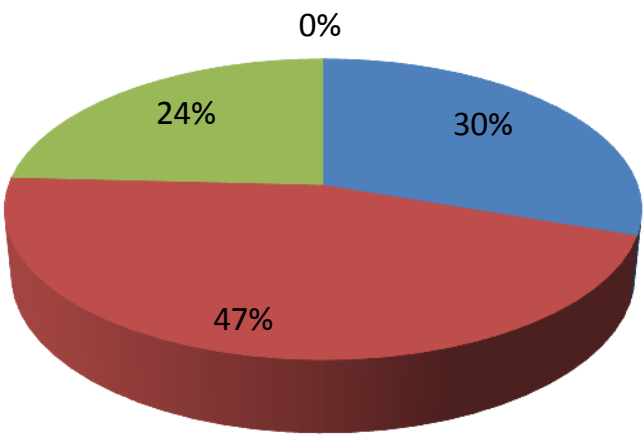

$$
\begin{aligned}
& \text { Less than rs.100 } \\
& \text { Between rs.100 } \\
& \text { to rs. } 500 \\
& \text { Between rs. } 500 \\
& \text { to rs.1000 } \\
& \text { More than } \\
& \text { rs.1000 }
\end{aligned}
$$

\begin{tabular}{|c|c|c|c|c|c|}
\hline \multicolumn{2}{|c|}{ Parameter } & Responses & $X^{2}$ (Calculated) & $\mathrm{X}^{2}$ (Tabulated) & D.F \\
\hline \multirow{5}{*}{$\begin{array}{l}\text { Bakery } \\
\text { products }\end{array}$} & Cookies & 21 & \multirow{5}{*}{0.755886} & \multirow{5}{*}{9.488} & \multirow{5}{*}{4} \\
\hline & Biscuits & 40 & & & \\
\hline & Pastry & 25 & & & \\
\hline & Cake & 21 & & & \\
\hline & Others & 3 & & & \\
\hline \multirow{2}{*}{$\begin{array}{c}\text { Frequency of } \\
\text { buying }\end{array}$} & Daily & 15 & \multirow[b]{2}{*}{0.755886} & \multirow[b]{2}{*}{7.815} & \multirow[b]{2}{*}{3} \\
\hline & Weekly & 47 & & & \\
\hline
\end{tabular}

Figure 13: Responses for money spend on bakery products

Table 4: Chi-square Test result $(P=0.05)$ 


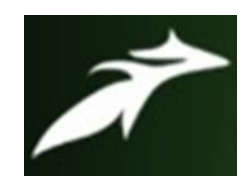

Shravan Choudhary et al, International Journal of Advances in Agricultural Science and Technology,

Vol.8 Issue.3, March-2021, pg. 1-9

ISSN: 2348-1358

Impact Factor: 6.057

NAAS Rating: 3.77

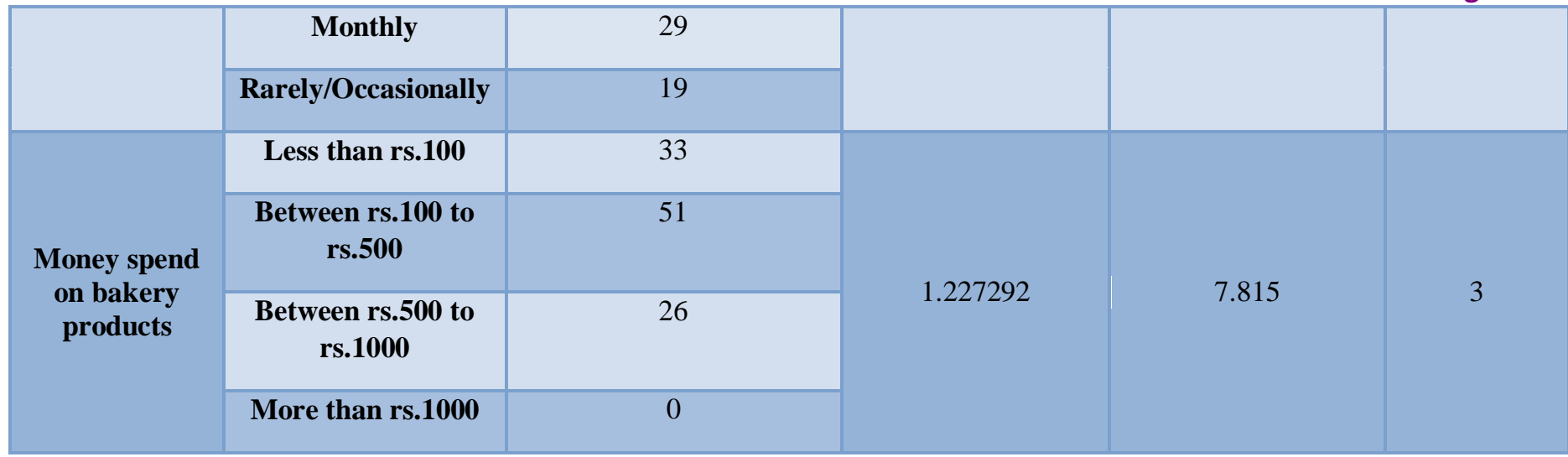

Results obtained from research shows for different bakery products 21 responses were for cookies, 40 responses were for biscuits, 25 responses were for pastry, 21 responses were for cake and 3 responses were for others. For frequency of buying 15 responses were for daily, 47 responses were for weekly, 29 responses were for monthly and 19 responses were for rarely/occasionally. Maximum people 51 out of 110 (40 male and 11 female) spend between rs.100 to rs.500 on bakery products. 26 people ( 21 male and 5 female) spend between rs.500 to rs. 1000 and 33 people ( 29 male and 4 female) spend below rs.100. In the scope of the study, brand dependency level of cookies, biscuit, pastry, cake and other products was also investigated. Consumer preference for bakery products were evaluated in four groups according to the brand loyalty ratings as described by Kotler et.al (1997) .In bakery products; those who always choose the same brand, or those who buy a brand are "absolute", 2 or 3 brands are "strong", those who prefer certain brands for a certain period of time are "middle", those who does not prefer a particular brand or prefer frequently change brands are the "independent" defined as consumer mass. When brand loyalty levels of consumers were evaluated according to Table 3; biscuit brand dependency was found to be strong. As a matter of fact, the share of brands with strong brand dependency ( 2 and 3 brands) was $59 \%$. The average purchasing frequency of bakery products was also examined. The $14 \%$ of the total individuals were daily, $43 \%$ in week, $26 \%$ in one month and 17\% purchase rarely or occasionally. To determine the acceptance and reliability of the data, chi-square test was performed and a strong relationship between categorical variables obtained (Table 3) which is similar to the findings of the research done by Gul et.al (2017) for bakery products consumption and consumers' awareness in urban areas of isparta city, turkey. In his findings, it was determined that brand-dependency was strong in other bakery products. The ratio of those who always prefer the same brand in bread was $43.06 \%$, the ratio of those who prefer two or three brands was $28.13 \%$, the ratio of those who prefer certain brands at certain times was $10.07 \%$ and the ratio of those who do not have brand preference was $18.75 \%$. The ratio of those who always prefer the same brand in pastry-cake products was determined as 34.38\%, the ratio of those who prefer two or three brands was $22.57 \%$, the percentage of those who prefer certain brands in certain times was $15.63 \%$ and the rate of those who do not have brand preference was determined as $27.43 \%$. In brand dependency ratios for pasta, 39.93\% of those who always prefer the same brand and $38.19 \%$ of those who prefer two or three brands. The percentage of those who preferred certain pasta brands at certain times was $11.46 \%$. The rate of non-branded pasta was $10.42 \%$. When purchasing wafers and varieties, the percentage of consumers who always prefer the same brand is $38.54 \%$. The proportion of those who prefer two or three brands was $36.46 \%$. The percentage of those who preferred specific brands for a certain period of time was 7.64\% and the percentage of consumers who did not have brand preference was 7.64\%. Money spend by consumers on bakery products describe their preference towards bakery products. Present research shows that highest frequency of money spend is for 100 to 500rs in one visit to the bakery shop (Table3) and similar results was find by Khanna (2016) that majority of the respondents which is 39 percent spend an average amount of money between 100 to 500 rupees on bakery products when they visit the bakery shops. 37 percent of the total respondents are those who buy the bakery products worth 500 to 1000 from the bakery shops in their single visit. While only 11 percent of the total respondents are those who spend less than 100 rupees for buying the bakery products from the bakery shops in one visit. 


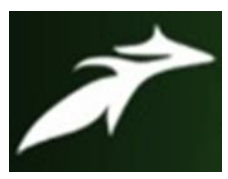

Shravan Choudhary et al, International Journal of Advances in Agricultural Science and Technology,

Vol.8 Issue.3, March-2021, pg. 1-9

ISSN: 2348-1358

Impact Factor: 6.057

NAAS Rating: 3.77

\section{Conclusion}

Today, bakery industry is rapidly growing industry so behaviour of consumers towards baked product is important to know. In this research various responses was recorded for different parameters. According to the research, consumers show a positive behaviour towards bakery products. In this research, factors affecting consumer buying decision and consumer behaviour towards bakery product were studied. In overall research this is observed that people consume bakery products frequently and there are various factors like taste, texture, smell, fortification etc. which affects consumers buying decision.

\section{References}

[1]. Abd Elmoneim O. Elkhalifa , Abdullahi H. El-Tinay (2002), Effect of cysteine on bakery products from wheat-sorghum blends, 2002 Elsevier Science Ltd., PII: S0308-8146(00)00325-3

[2]. Fernando Rodriguez-Artalejo, Esther Lopez Garcia, Lydia Gorgojo, Carmen Garces, Miguel Angel Royo, Jose Maria Martin Moreno, Mercedes Benavente, Alfonso Macias and Manuel de Oya (2003) Consumption of bakery products, sweetened soft drinks and yogurt among children aged 6-7 years: association with nutrient intake and overall diet quality, British Journal of Nutrition (2003), DOI: 10.1079/BJN2002787

[3]. Pieter Decock and Stefan Cappelle (2004), Bread technology and sourdough technology, 2004 Elsevier Ltd., doi:10.1016/j.tifs.2004.04.012

[4]. Gyu-Young Hura , Dong-Hee Kohb , Hyoun-Ah Kima , Han-Jung Parka , Young-Min Yea , Kyoo-Sang Kimb , Hae-Sim Parka (2007) Prevalence of work-related symptoms and serum-specific antibodies to wheat flour in exposed workers in the bakery industry, 2007 Elsevier Ltd. , doi:10.1016/j.rmed.2007.11.015.

[5]. M. Pacin, S.L.Resnik, M.S.Neira, G Molto \& E.Martinez (2009), Natural occurrence of de-oxynivalenol in wheat, wheat flour and bakery products in Argentina, DOI: 10.1080/02652039709374534

[6]. Aleksandar Maric, Slavko Arsovski (2010), The Level of Customer Satisfaction as one of the Goals of the Quality of the Organization in the Bakery Industry, 4th International Quality Conference May 19th 2010 Center for Quality, Faculty of Mechanical Engineering, University of Kragujevac

[7]. James P. Smith , Daphne Phillips Daifas, Wassim El-Khoury , John Koukoutsis \& Anis El-Khoury (2010), Shelf Life and Safety Concerns of Bakery Products—A Review, Taylor and Francis Inc. ISSN: 1040-8398 DOI: 10.1080/10408690490263774

[8]. P.Saranraj and M.Geetha (2011), Microbial Spoilage of Bakery Products and Its Control by Preservatives, ISSN 0976 - 3333 , www.ijpba.info

[9]. J. Martínez-Monzo, P.García-Segovia \& J.Albors-Garrigos (2013) Trends and Innovations in Bread, Bakery, and Pastry, Journal of Culinary Science \& Technology, 11:1, 56-65, DOI: 10.1080/15428052.2012.728980

[10].Hemraj N. Patil and Rajeshree Pol (2014) a study on effects of standardized recipes of bakery products in pune region, ijmc.editor@ rtmonline.in| http://ijmc.rtmonline.in | ISSN 2349-073X

[11].Quiroga Souki, Gustavo, Costa Reis, Viviane, Cunha Moura, Luiz Rodrigo (2016) The behavior of bakery consumers, http://www.redalyc.org/articulo.oa?id=87846407002

[12].Hulya Gul, Fidan Merve Kart, Mevlut Gul, Metin Goksel Akpinar (2017) Bakery products consumption and consumer's awareness in urban areas of Isparta City, TURKEY, Scientific Papers Series Management, Economic Engineering in Agriculture and Rural Development Vol. 17, Issue 2, 2017 PRINT ISSN 2284-7995, E-ISSN 2285-3952

[13].Dr. V. Kannan (2017), Customers preference and attitude towards Britannia products - a study with special reference to Theni district Tamilnadu, ISSN(Print) 2249-0302 ISSN (Online)2231-2528, International Journal of Management Studies

[14].Anoop Yadav , V.K. Garg (2018) Biotransformation of bakery industry sludge into valuable product using vermi-composting, https://doi.org/10.1016/j.biortech.2018.12.023.

[15].Mohsen Gavahian, Yan-Hwa Chu, Jose M. Lorenzo, Amin Mousavi Khaneghah \& Francisco J. Barba (2018), Essential oils as natural preservatives for bakery products: Understanding the mechanisms of action, recent findings, and applications, https://doi.org/10.1080/10408398.2018.1525601 